\title{
研 究 論 支
}

\section{運動が膝蓋腱反射に与える影響}

嶋田誠一郎1)佐々木伸一井村慎一2) 跲木一弘31

The Influence of Exercise on Patellar Tendon Reflex.

Seiichirou SHIMADA, RPT' ${ }^{1}$, Shinichi SASAKI, RPT, Shinichi IMURA, MD ${ }^{2}$, and Kazuhiro SUZUKI, RPT ${ }^{31}$.

1) Department of Physical therapy, 2) Department of Orthpeadic Surgery, Fukui Medical College Hospital : 23-3 Simoaituki Matsuoka-cho Yoshida-gun Fukui 910-11 Japan.

TEL 0776-61-3111. 3) Toyohashi National Hospital.

J. Exerc. Physiol. 3(2):75-80, 1988. ISSN 0912-7100. Received Feb. 8, 1988. ABSTRACT

This study was performed in order to investigate the influence of exercise on muscle tone using the result of patellar tendon reflex. Subjects consisted of 23 healthy people, and 8 patients who were hyperflexia of patellar tendon reflex. And after each performed isokinetic exercise of the knee, measured amplitude of patellar tendon reflex. Healthy subjects showed a significantly longeramplitude at one,

three,and five minutes after the exercise than that before the exercise. With respect to the patients, a significant increase in amplitude was observed at one and three minutes after the exercise. The results suggeted that incase physical thera py is performed on the patient who must consider the state of muscle tone, it is necessary to regulate both intensity and intervals of the exercise.

Key Words; patellar tendon reflex, muscle tone, knee extension and flexion exercise 要旨

滕盖腱反射を通して運動が筋毉張に与える影響を推察する事を目的とし、以下の研究を行っ た。研究は、健常者 23 例、滕蓋腱反射六進を示す症例 8 例に対し滕関節屈曲伸展の交互等速 度運動を行わせ、滕盖腱反射に与える影響を経時的に測定した。その結果、等速度運動終了後、 健常者で運動開始前との間に運動終了後 1 分、同 3 分、同 5 分で有意な振幅の増加が認められ た。症例では、運動終了後 1 分および同 3 分で運動開始前との間に有意な増加が認められた。 本研究により理学療法を試行する際、筋緊張を考慮したい症例の場合は、運動の強度やインタ ーバルを調節する必要性が示唆された。 キ们ード: 膝蓋腱反射、筋緊張、様屈伸運動

1)福井医科大学附属病院理学療法部：福井県吉田郡松岡町下合月23-3( T910-11)
TEL 0776-61-3111.
2) 同 整形外科
3) 国立豊橋病院

運動生理 $3(2): 75-80,1988$ 受付日 1988 年 2 月 8 日. 


\section{I はじめに}

筋緊張の程度は、我々が理学療法を施行す る場合において重要な考慮事項である。筋腎 張の六進は運動障害の一因をなしている場合 が多いがその一方で、支持性として運動障害 を助け、A D L を向上させるケースもある。

筋㗨張、得に痤性を量的に把握する方法と して吉元1)は、以下の 4 つに分類している。

(1) 腱反射を測定する方法

(2) 伸張反射を測定する方法

（3）H波を測定する方法

(4)動作による測定

その中でも(1)の腱反射は,最も簡便かつ一 般的な臨床的検査法の一つである。腱反射は、 運動あるいは物理療法など種々の要因によっ て促通又は抑制される事が報告されている4 5) 6 1 7)。そこで今回我々は、滕盖腱反射を通 して運動が筋緊張に与える影響を推察する事 を目的に以下の研究を試みた。本研究は、健 常者および膝盖腱反射六進を示す症例に対し 最大努力にて滕関節屈曲 ・伸展の交互等速度 運動を行わせ、運動終了後の滕蓋腱反射の振 幅に与える影響を経時的に測定した。

\section{II 対 象}

健常群は、男性 11 例 · 女性 12 例 ·計 23 例で、 年齢は16歳から67歳（男性 $31.1 \pm 24.2$ 歳、女

表 1 症例の内訳

\begin{tabular}{|c|c|c|c|c|}
\hline 彭断名 & 年龄 & 性別 & 測定肢 & $\mathrm{PTR}$ \\
\hline 脳梗塞 (BRS V) & 50 & 男 & 左 & $++t$ \\
\hline 脳梗塞(BRS V) & 62 & 男 & 左 & $++t$ \\
\hline 脳性麻瘦（痉直型両麻瘙） & 38 & 男 & 右 & $+++t$ \\
\hline 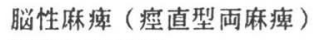 & 15 & 女 & 右 & +++ \\
\hline 澒髄不全損稘 & 23 & 男 & 左 & $++t+$ \\
\hline 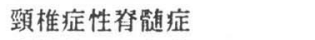 & 65 & 男 & 右 & $++t$ \\
\hline 冷髄性不全麻㾝 & 54 & 女 & 右 & ++ \\
\hline 多発性硬化症 & 47 & 男 & 左 & $++t$ \\
\hline
\end{tabular}

性 $36.6 \pm 16.5$ 歳）であり、測定肢は右 14 例、 左9例であった。症例群は滕蓋腱反射六進を 示す男性 6 例, 女性 2 例, 計 8 例で、年齢は15歳 から 66 歳（平均 $44.3 \pm 17.8$ 歳）であった。症 例の内訳を、表 1 に示す。測定肢は脳梗塞後 遺症患者では患側、その他は滕蓋腱反射方進 の著明な下肢側を測定した。

III 方 法

滕蓋腱反射振幅の測定は,被検者をCybexテ ーブル上で 10 分間安静坐位をとらせた後、運 動開始前. 運動終了後 1 分 ·同 3 分 - 同 5 分. 同 10 分・同 20 分 ·同 30 分 ·同 40 分に行った。 運動負荷として、Lumex 社製Cybex ー II によ り回転速度 30 度/秒にて最大努力による滕関 節屈曲・伸展の交互等速度運動を連綍 10 回行 わせた。

腱叮打の強度は、模擬実験の結果より最大 上刺激となるようハンマーの落下位置を設定 した。被検者には、膝関節電気角度計を装着 させ、膝蓋腱反射の振幅を日本電気三栄社製 Visilight5Mにて紙送り速度 $0.5 \mathrm{~cm} /$ 秒で記録 した。振幅は、下腿自然下垂位を０度とし、 腱叮打後の最大伸展を各腱叮打試行 5 回のう ち、最大と最小を除いた 3 回の平均値として 表した。測定時室温は21.9 1.7 度、測定時 刻は一律には定めなかった（図1）。

IV 結 果

(1) 健常群の振幅の経時的変化

健常群の等速度運動負荷による総仕事量は、 膝関節伸展 $1093 \pm 438 \mathrm{ftlbs}$ 、同屈曲で $612 \pm$ $329 \mathrm{ftlbs}$ であった。図 2 は健常群の運動開 始前および運動終了後の振幅の経時的変化で ある。運動開始前では $21.6 \pm 7.5$ 度であった が、運動終了後 1 分で $30.1 \pm 8.9$ 度に達し、以 


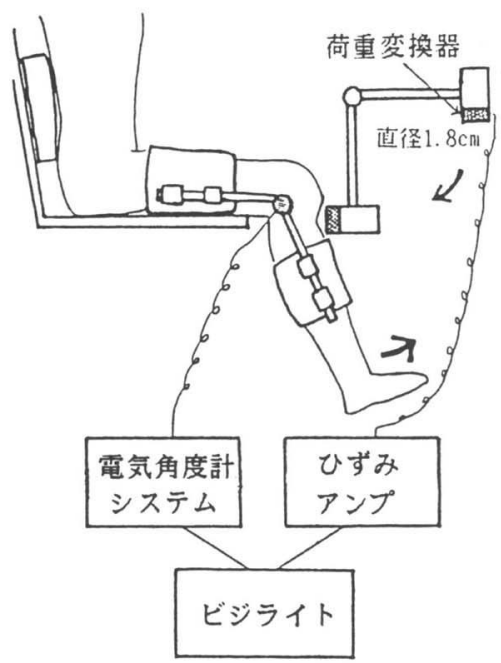

図 1 眎蓋腱反射测定システム
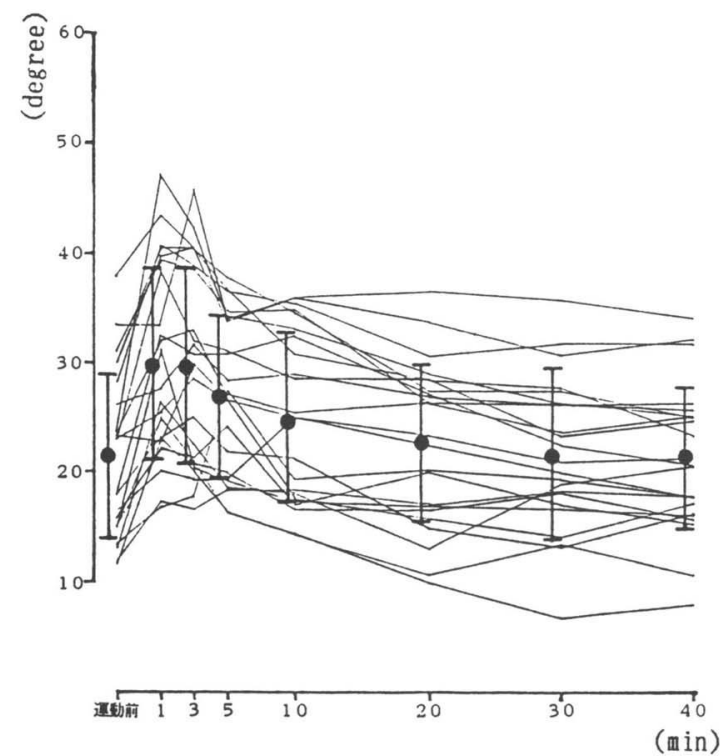

図2健常群における振幅の経時的変化

降振幅は徐々に低下した。振幅の最大となる 測定時間は、運動終了後 1 分 14 例、同 3 分 8 例、 同 5 分 1 例で、運動開始前との間に、運動終了 後 1 分、同 3 分および5分にて有意差が認めら れた（p<0.01）。しかし運動終了後10分以降 では有意差は認められなかった。

健常群の男女差に関しては、男性の方に運
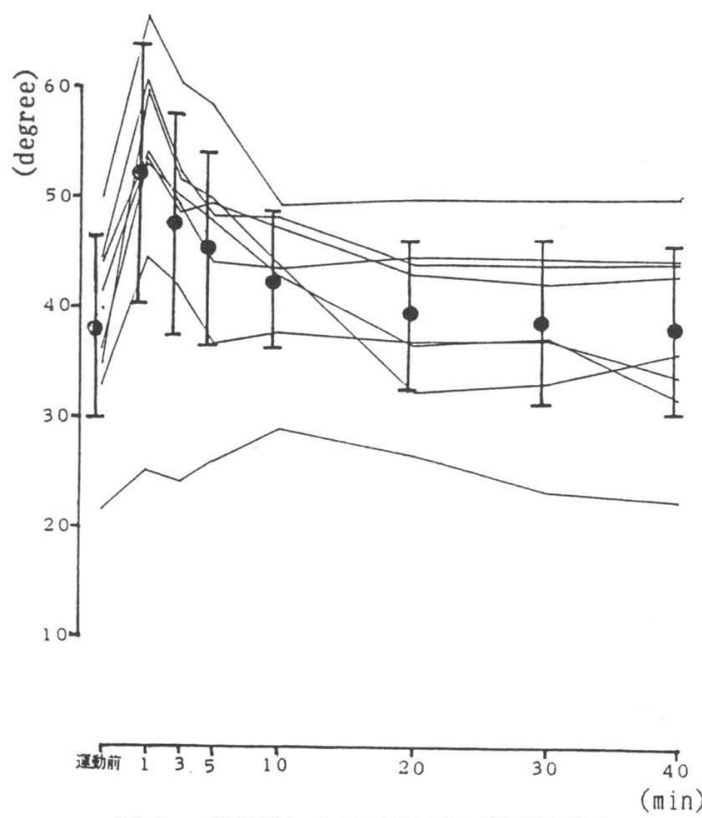

図3症例群における振幅の経時的変化

動開始前および運動終了後のいずれにおいて も振幅が高值となる傾向を示した。個々の膝 伸展角度の最大となる測定時間は、男性では 運動終了後 1 分 8 例、同 3 分 3 例で、女性では運 動 終了後 1 分 6 例、同 3 分 5 例、同 5 分 1 例であり、 女性でやや遅延する傾向を示した。

(2) 症例群の振幅の経時的変化

症例群の等速度運動負荷による総仕事量は、 滕関節伸展 $684 \pm 291 \mathrm{ftlbs}$, 同屈曲 $268 \pm 130$ $\mathrm{ftl}$ bsであった。図 3 は症例群の運動開始前 および運動終了後の振幅の経時的変化である。 運動開始前では $38.1 \pm 8.8$ 度であったが、運 動終了後 1 分で $52.1 \pm 12.6$ 度に達し、以降振 幅は徐々に低下した。個々の振幅の最大とな る測定時間は、運動終了後 1 分 7 例、同 10 分 1 例であり、後者の 1 例は、運動終了啳も振幅 の增加が著明ではなかった春髄性不全麻㾝の 症例であった。運動前と運動終了後 1 分およ び同3分の間にて有意差が認められた（p〈 0.05) が、運動終了後5分以降では有意差は 認められなかった。 


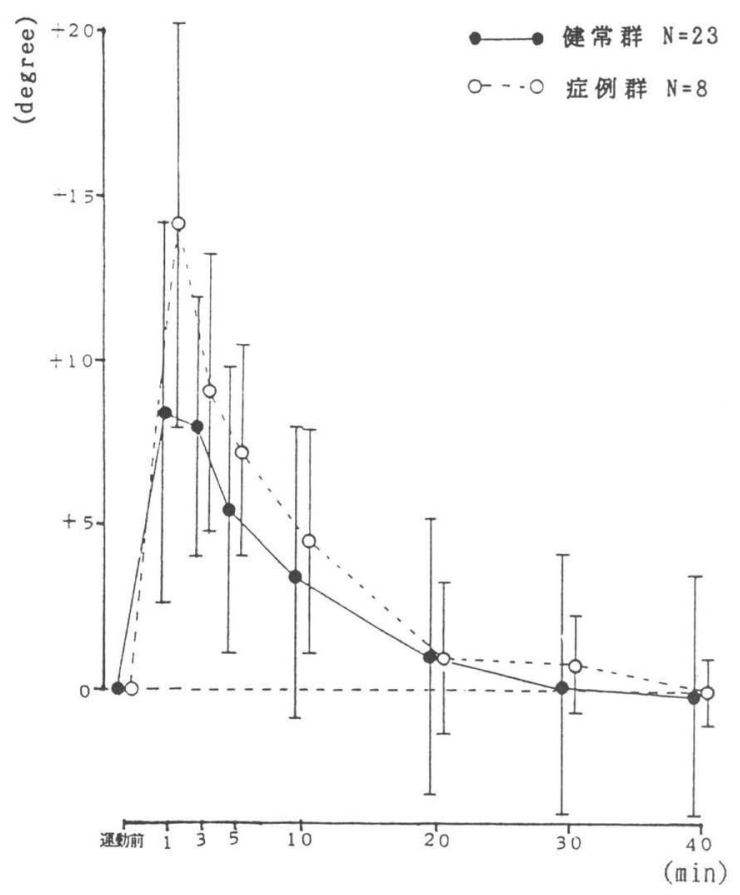

図 4 健常群と症例群の振幅增加値の比較

(3) 健常群と症例群との比較

症例群では、健常群と比較して運動開始前 で平均 16.5 度、運動終了後 1 分で 22.0 度、同 3 分 17.6 度、同 5 分 18.2 度、同 10 分 17.4 度、同 20 分 16.5 度、同 30 分 17.1 度、同 40 分 16.7 度の 高値を全体を通して示した。図 4 は、運動開 始前の振幅を 0 度とし、運動終了後の振幅の 增加分を増加值として表したものである。健 常群では、運動終了役 1 分で $8.5 \pm 5.8$ 度、同 3 分で $8.0 \pm 4.1$ 度の增加を示し、以降増加値 は次第に減少した。運動終了後 1 分と同 3 分の 間に有意な減少は認められなかった。一方症 例群では、運動終了後 1 分で $14.0 \pm 6.2$ 度、 同 3 分で $9.0 \pm 4.4$ 度と両測定時間の間に有意 な減少が珰められた（p<0.05）。健常群では、 増加値の減少曲線は、鈍角な曲線を描いたの に対し、症例群では鋭角な曲線を示した。ば らつきは、健常群では各測定間に著明な差は みられなかったが症例群では、運動終了後次 第に収歛されてゆく傾向を示した。

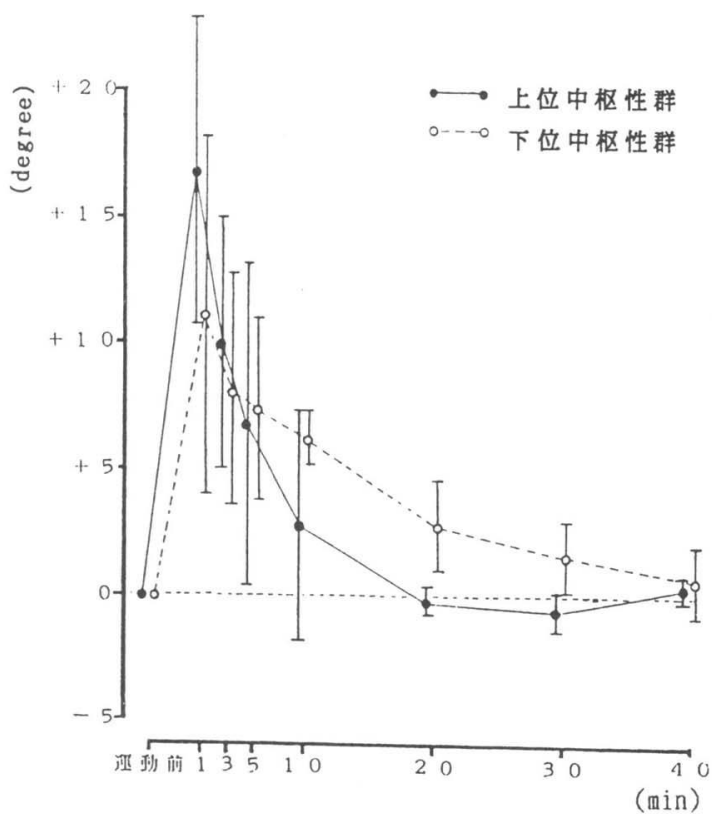

図 5 中枢の障害レペルによる比較

(4) 中枢の障害レベルによる比較

中枢の障害レベルの違いによる運動が膝蓋 腱反射に与える影䉕を比較するために、症例 群を上位中枢性群（延觬レベル以上）と下位 中枢性群（脊鰱レベル）とに分類した。上位 中枢性群は 4 例（平均年齢 $41.3 \pm 20.1$ 歳）で、 下位中枢性群も同様に 4 例（平均年齢 $47.3 \pm$ 17.8歳）である。等速度運動負荷による総仕 事量は、上位中枢性群で膝関節伸展 $513 \pm 280$ $\mathrm{ftlbs}$ 、同屈曲193土801 ftlbsであり、下位 中枢性群で滕関節伸展 $854 \pm 202 \mathrm{ftlbs}$ 、同屈 曲 $344 \pm 133 \mathrm{ftlbs}$ であった。

図 5 は、両群での振幅增加值の経時的変化 を表している。上位中枢性群では、運動終了 後 1 分で $16.9 \pm 6.1$ 度、同 3 分で $9.9 \pm 4.6$ 度、 同 5 分で $6.8 \pm 6.4$ 度、同 10 分 $2.9 \pm 4.5$ 度であ った。一方下位中枢性群では、運動終了後 1 分で $11.2 \pm 5.6$ 度、同 3 分で $8.2 \pm 4.6$ 度、同 5 分で $7.5 \pm 3.4$ 度、同 10 分で $6.2 \pm 1.1$ 度であ った。上位中枢群では運動終了後振幅の増加 が著明であり、又減少も急激であった。それ 
に対し下位中枢性群では、運動終了後の振幅 の增加もさほど著明ではなく、又減少もゆる やかであった。

\section{$\mathrm{V}$ 考 察}

健常者に関して石河ら ${ }^{9)}$ は、波労という立 場から滕蓋腱反射の程度は疲労の初期に減退、 中期に六進し、さらに疲労が著しくなれば減 退するとし、中期の充進は、上位の中枢で抑 制されていた反射中枢が抑制から解放される (disinhibition) ためと考えられるとしてい る。同じく健常者の滕蓋腱反射と運動との関 わりについて和久井ららは、P N F のリズム 的安定化手技を使用し、一側下肢を㬵伸展挙 上 45 度位にて検者の徒手抵抗に抗して膝関 節屈曲・伸展 3 回の等尺性収縮を最大努力に て行わせた。その結果、促通手技後、滕盖腱 反射閥值の低下を慧めたとしている。今回の 研究においても健常者の運動後の滕蓋腱反射 の充進が振幅の増加という結果として確認で きた。

片麻㾝患者の著しい筋緊張充進が患者の $\mathrm{A}$ D L に与える数々の悪影響については異論の ないところである。石田 ${ }^{10)}$ は,痤縮筋の場合、 強い抵抗に逆らって行う動作では痤縮は增強 されるとしている。今回の研究でも脳梗塞後 遺症片麻㾝患者 2 例でそれを裹付ける結果を 得ただけではなく、脳性麻㾝や春蹃性疾患な ど他の痤性麻㾝患者においても同様の結果を 得た。又本研究では、これらの痙性麻㾝患者 の運動後の振幅増加が運動前のレベルに低下 するためには、おおよそ 3 分の安静時間を必 要とした。これらの結果より我々が理学療法 を施行する際、筋緊張を考虑したい症例の場 合は、運動のインターバルを調節する必要性 が示唆される。それと共に最大努力を避ける など運動の强度も考虑する必要性が考えられ る。
中枢の障害レベルによる比較については、 未だ症例数も少なく今後の検討課題の一つで ある。下位中枢性疾患での振幅の妄進が比較 的ゆるやかであるのに対し、上位中枢性疾患 では克進が著明であることから、より愪重な 運動療法による負荷の調節が必要と考えられ る。しかし下位中枢性疾患では六進が持続す る傾向がみられるため、運動療法負荷が筋緊 張に与える加重効果を今後とも検討する必要 がある。

VI おわりに

今回我々は、運動が筋腎張に与える影響を 推察する事を目的に、運動と睖蓋腱反射との 関係を研究した。今後は、更に運動の強度や 運動の方法の点について検討が必要であると 考えられる。又、凌蓋腱反射に対し振幅のみ による分析を行ったが、腱叮打の闏値・睖伸 展の速度あるいは拮抗筋の収縮を考虑する上 での筋電図による分析等が必要と考えられる。

なお本論文の要冒は、第 22 回日本理学療 法士学会にてロ演した。

\section{参考文 献}

1) 吉元洋一：痤性の評価と運動療法. 第22 回日本理学療法士協会全国研修会抄録、 1987.

2) Wartenberg $R$ :Pendulousness of legs as diagnostic test. Neurology 1:18-24, 1951.

3) Baid T, et al:Electrical Stimulationin Treating Spasticity Resulting from Spinal Cord Injury, Arch Phys Med Rehab 66:515-517, 1985.

4) 明石謙、岡本卓爾: 痤縮の評価と物理療法、 
総合リハ 3:801-809, 1975.

5 ) 和久田佳代、中川一彦：健常下肢に対する ファシリテーションテクニックの影響

ーリスム的安定化の効果についてー、

理学療法 13:159-165, 1987.

6 ) 神沢信行：中枢神経疾患（痤性を含む）の

温熱・寒冷療法、理学療法 1:195-201, 1984.

7) Hartviksen K: Ice Thrapy in Spasticity.
Acta Neurol Scand 38:79-84,1962

8) 柳沢健：足関節、足部に対する P N F アプ ローチー理論と治療効果について一、 理学㙩法学 13:99-102, 1986.

9)石河利寛、松井秀治：スポーツ医学、杏林 書院、 1987.

10)石田睴: 痤縮と固縮に対するリハビリテー ションからのアプローチ． 総合リハ 14: 349-357, 1986. 